\title{
PENGEMBANGAN PANGAN FUNGSIONAL BUBUR INSTAN RENDAH INDEKS GLIKEMIK BERBASIS PANGAN LOKAL
}

\author{
The development of low glycemic index instant porridge as functional food based on \\ local food \\ Juenita Elfunam Mado $^{1 *}$, Dekie Rawung ${ }^{1}$, Mercy Taroreh $^{1}$ \\ ${ }^{1}$ Program Studi Ilmu Pangan \\ Pascasarjana Universitas Sam Ratulangi \\ Jl. Kampus UNSRAT, Manado 95115 \\ *Email: juenitamado24@gmail.com
}

\begin{abstract}
The purpose of this study was to analyze the nutritional content and glycemic index value of local food-based instant porridge products. The research method used was experimental research with the determination of the glycemic index using a one-shot case study design on a sample of white rats (Rattus novergicus). The results obtained in this study are the glycemic index value of instant porridge which is included in the low GI category, namely goroho plantain 31,88 , baruk sago 39,43 , and "mulubebe" plantain instant porridge 43,35. Meanwhile, instant porridge that has medium GI is mocaf 59,34. The results of the calculation of the glycemic load of instant porridge which has a low glycemic load are goroho plantain 8.17 , while those which have a moderate glycemic load are "mulubebe" plantain 11.88 , baruk sago 12.02 and mocaf 17.16 . So that the use of carbohydrate sources from different local foods, namely goroho plantain flour, "mulubebe" plantain flour, baruk sago flour, mocaf flour in instant porridge affects the glycemic index value of instant porridge.
\end{abstract}

Keywords: Instand porridge, glycemic index, plantain, mocaf, sago.

\section{PENDAHULUAN}

Indonesia adalah negara berkembang yang mempunyai bermacam permasalahan kesehatan seperti penyakit tidak menular. Seiring meningkatnya jumlah penderita penyakit tidak menular menyadarkan sebagian masyarakat tentang pentingnya menjaga kesehatan. Hal ini berdampak terhadap perubahan pola hidup dan kebiasaan konsumsi pangan masyarakat yang lebih memilih pangan yang sehat termasuk pangan fungsional.

Pangan fungsional merupakan pangan alami ataupun pangan olahan yan mengangdung satu atau lebih senyawa yang mempunyai fungsi fisiologis tertentu yang dapat memberikan manfaat terhadap kesehatan (Nurakhirawati dkk, 2016). Masalah kesehatan berupa penyakit tidak menular dapat dicegah dengan mengkonsumsi pangan fungsional 
(Abbas, 2020). Saat ini masyarakat lebih menyukai makanan dan minuman yang serba praktis dalam bentuk penyajian maupun pembuatannya tanpa mengurangi pemenuhan zat gizi yang diperlukan. Sehingga diperlukan diversifikasi pangan untuk membuat produk pangan yang dapat mengatasi masalah ini.

Salah satu pangan fungsional yang dapat dikembangkan yaitu produk pangan fungsional berupa bubur instan. Bubur instan adalah bubur yang sudah mengalami proses pengolahan lebih lanjut sehingga saat disajikan tidak dibutuhkan proses pemasakan lagi (Fransiska, 2018). Bubur instan bertekstur lunak sehingga mudah dicerna dan saat disajikan hanya perlu ditambahkan air panas agar mudah larut dan mudah dikonsumsi (Anandito dkk, 2016).

Adanya potensi yang melimpah dan serta belum banyak dimanfaatkan maka pangan lokal sumber karbohidrat seperti sagu, pisang dan umbi-umbian dapat dimanfaatkan sebagai bahan pangan alternatif yang lebih aman dalam penyediaan energi bagi tubuh serta dapat menjadi pangan fungsional yang meningkatkan status kesehatan masyarakat khususnya dalam mencegah resiko penyakit tidak menular. Pangan sumber karbohidrat yang digunakan dapat dimanfaatkan yaitu pisang goroho, pisang "mulubebe" indigenous Halmahera Utara, sagu baruk dan tepung mocaf.

Pisang menjadi salah satu komoditi buah tropis yang mempunyai nilai IG rendah yang berikisar antara 4651 (Rimbawan dan Siagian, 2004). Pisang goroho adalah pisang spesifik khas Sulawesi Utara. Menurut Nurali dkk (2012) pisang goroho memiliki kandungan karbohidrat $75,18 \%$ dengan serat sebanyak $5,12 \%$ dan proporsi pati sebanyak $70,78 \%$ yang $39,59 \%$ amilosa dan $31,19 \%$ amilopektin. Pisang "mulubebe" merupakan komoditas lokal dari Halmahera Utara. Penelitian Lumba dkk (2019) menyebutkan pisang "mulubebe" warna orange mengandung karbohidrat yang tinggi yaitu $80,81 \%$, protein $4,41 \%$, lemak $1,03 \%$ dan serat $0,92 \%$.

Sagu baruk merupakan sumber karbohidrat yang banyak tumbuh di daerah Sulawesi Utara dan Maluku. Tepung sagu baruk mengandung karbohidrat sebesar 90,61\% dengan serat sebesar 2,25\% (Tarigan dkk, 2015). Sedangkan tepung mocaf merupakan tepung ubi kayu yang diproduksi dengan memodifikasi sel ubi kayu secara fermentasi. Tepung mocaf memiliki karbohidrat sebesar $85-87 \%$ dan kadar pati resisten sebesar $12,51 \%$ (Setiarto, 2018).

Konsep lama berpendapat semua pangan sumber karbohidrat memiliki pengaruh yang sama dalam meningkatkan kadar glukosa dalam darah. Tetapi, pada konsep indeks glikemik (IG), dijelaskan bahwa tidak semua jenis pangan sumber karbohidrat mempunyai pengaruh yang sama dalam meningkatkan kadar glukosa dalam darah (Diyah dkk, 2016). Indeks glikemik pangan ialah kemampuan bahan pangan meningkatkan kadar glukosa dalam darah. Konsep indeks glikemik ini dapat digunakan sebagai acuan untuk menentukan jumlah dan jenis pangan sumber karbohidrat yang tepat dalam meningkatkan serta memelihara asupan pangan yang sehat.

Beberapa penelitian sebelumnya menyebutkan bahwa penggunaan sagu, pisang, dan tepung mocaf dalam formulasi produk pangan berpengaruh terhadap daya cerna pati, komposisi zat gizi, dan kadar serat pangan sehingga dapat menurunkan nilai indeks glikemik pangan dan menekan laju penyerapan glukosa (Kustanti dkk, 2017; Puspita dkk, 2019; Spiraliga dkk, 2017; Warsito dan Sa'diyah, 2019). Penelitian mengenai indeks glikemik bubur instan berbasis pangan lokal belum banyak dilakukan. 
Penelitian bertujuan untuk menganalisis indeks glikemik bubur instan berbasis pangan lokal.

\section{METODE PENELITIAN}

\section{Bahan dan Alat}

Subjek penelitian ini yaitu 12 ekor tikus jenis Rattus Novergicus galur Wistar, berjenis kelamin jantan, berumur 2-3 bulan, berat badan tikus 150-200 g, tikus dalam keadaan sehat dan belum pernah dipergunakan dalam penelitian, dan kadar glukosa darah awal tikus $<110$ $\mathrm{mg} / \mathrm{dl}$ dan glukosa darah setelah diinduksi aloksan adalah $\geq 200 \mathrm{mg} / \mathrm{dl}$.

\section{Rancangan penelitian}

Jenis penelitian yang digunakan adalah eksperimen dengan analisis indeks glikemik menggunakan desain rancangan one-shot case study pada sampel tikus putih (Rattus novergicus).

Formulasi bubur instan yang dibuat terdiri dari empat formula dengan menggunakan sumber karbohidrat yang berbeda. Penyusunan formula berdasarkan komposisi gizi bahan utama per $100 \mathrm{~g}$ bahan. Persentasi keempat formulasi bubur instan berbasis pangan lokal yaitu :

1. F01 : $70 \%$ tepung pisang goroho + $25 \%$ tepung tempe $+5 \%$ minyak kedelai

2. F02 : 70\% tepung pisang "mulu bebe" $+25 \%$ tepung tempe $+5 \%$ minyak kedelai

3. F03 : $70 \%$ tepung sagu baruk $+25 \%$ tepung tempe $+5 \%$ minyak kedelai

4. F04 : $70 \%$ tepung mocaf $+25 \%$ tepung tempe $+5 \%$ minyak kedelai

Setelah formulasi selanjutnya dilakukan pembuatan tepung pangan lokal. Bubur instan dibuat dengan menggunakan metode dry mixing (pencampuran bahan kering). Proses pencampuran dilakukan secara manual dengan mengocok bahan dalam kantong plastik selama kurang lebih 5 menit.
Campuran bahan ditambahkan air sebanyak $60 \%$ dari total bahan, lalu dimasak selama 10 menit pada suhu $75^{\circ} \mathrm{C}$ hingga campuran bahan mengental. Bubur yang telah matang kemudian didinginkan dan dioleskan diatas Loyang yang sudah dilapisi aluminium foil, kemudian bubur dikeringkan dalam oven selama 3 jam dengan suhu $125^{\circ} \mathrm{C}$. Setelah kering, bubur dihaluskan dengan grider dan diayak dengan ayakan 80 mesh.

Tahapan selanjutnya adalah penentuan nilai indeks glikemik produk bubur instan. Sebelum penelitian, tikus dipuasakan \pm 10 jam (kecuali air putih). Sampel tikus yang masih dalam keadaan puasa kemudian diambil darahnya untuk mengukur kadar glukosa darah puasa. Sampel tikus kemudian diberi pangan acuan yaitu larutan glukosa murni yang mengandung 50 gram karbohidrat yang kemudian dikonversikan sesuai berat badan tikus.

Subjek penelitian diukur kadar glukosa darahnya pada menit ke-0 yaitu sebelum diberi pangan acuan maupun pangan uji. Setelah itu, subjek diukur kadar glukosa darahnya setiap 15 menit pada satu jam pertama dan setiap 30 menit pada satu jam kedua. Sehingga selama dua jam setelah pemberian pangan acuan, sampel darah tikus diambil secara berturut-turut pada jam ke-0, 15, 30, 45, 60, 90, 120 menit setelah pemberian pangan acuan. Pemberian pangan acuan glukosa murni diberikan pada hari pertama, kemudian bubur instan pisang goroho (F01), bubur instan pisang "mulubebe" (F02), bubur instan sagu baruk (F03), dan bubur instan mocaf (F04) pada hari-hari selanjutnya. Jarak pemberian antar pangan uji masingmasing 5 hari.

Hasil pengukuran kadar glukosa darah subjek yang ditebarkan dalam sumbu X (waktu pengambilan darah) dan sumbu Y (kadar glukosa darah) kemudian diolah dan membentuk kurva. Kurva 
tersebut kemudian dihitung luas daerah bawah kurva yang terbentuk. Luas daerah dibawah kurva digunakan untuk menghitung nilai indeks glikemik pangan uji.

\section{HASIL DAN PEMBAHASAN}

\section{Kandungan Gizi Bubur Instan Berbasis Pangan Lokal}

Masing-masing bubur instan berbasis pangan lokal ini dibuat dalam 100 gram bahan utama yaitu tepung. Berdasarkan keempat perlakuan yang berbeda pada jenis karbohidrat maka dihasilkan bubur instan yang berbeda. Berdasarkan hasil penelitian yang dilakukan peneliti, bubur instan berbasis tepung pisang goroho dan pisang "mulubebe" menghasilkan warna cokelat, bubur instan sagu baruk menghasilkan warna putih susu, dan bubur instan mocaf menghasilkan warna cokelat muda. Hasil kandungan gizi protein, lemak, karbohidrat dan serat bubur instan berbasis pangan lokal diperoleh dengan menjumlahkan kandungan gizi bahan baku sesuai dengan formulasi yang ditentukan. Hasil data dasar kandungan protein, lemak, karbohidrat, dan serat pada bahan baku tepung dikutip dari hasil penelitian sebelumnya. Kandungan gizi bubur instan dapat dilihat pada tabel 1 .

Hasil yang disajikan pada tabel 1 menunjukkan tentang kandungan protein, lemak, karbohidrat, dan serat pada setiap formula formula bubur instan yaitu bubur instan pisang goroho, bubur instan pisang "mulubebe", bubur instan sagu baruk, bubur instan mocaf. Jika dibandingkan dengan persyaratan bubur instan menurut SNI 01-7111.1-2005, maka kandungan

Tabel 1. Kandungan gizi bubur instan per $100 \mathrm{~g}$

\begin{tabular}{cccccc}
\hline $\begin{array}{c}\text { Komposisi Zat } \\
\text { Gizi }\end{array}$ & $\begin{array}{c}\text { SNI Bubuk } \\
\text { Instan* }\end{array}$ & F01 & F02 & F03 & F04 \\
\hline Protein & 8 s/d 22 & 17,41 & 16,67 & 13,94 & 15,15 \\
Lemak & 6 s/d 15 & 7,41 & 7,46 & 6,92 & 8,64 \\
KH & Maks. 77 & 56,98 & 60,92 & 67,78 & 64,28 \\
\hline
\end{tabular}

gizi pada formulasi bubur instan sesuai dengan batas persyaratan bubur instan yang ditetapkan. Dengan demikian, dapat dikatakan bahwa berdasarkan kandungan gizinya, formulasi bubur instan yang dihasilkan telah memenuhi pesyaratan mutu bubur instan.

\section{Nilai Indeks Glikemik Bubur Instan}

Hasil perhitungan jumlah porsi pangan uji yang mengandung 50 gram available carbohydrate dapat dilihat pada tabel 2.

Pemberian pangan uji pada subjek penelitian yang mengandung 50 gram available carbohydrate dikonversikan sesuai berat badan tikus 200 gram, sehingga jumlah porsi pemberian pangan uji pada tikus yaitu bubur instan pisang goroho sebanyak 1,72 gram, bubur instan pisang "mulubebe" sebanyak 1,52 gram, bubur instan sagu baruk sebanyak 1,38 gram, dan bubur instan mocaf sebanyak 1,43 gram. Formula bubur instan yang diberikan pada subjek penelitian dilarutkan dalam 2,5 ml air mineral. Berdasarkan hasil perhitungan dapat diamati bahwa jumlah porsi terbanyak adalah pada bubur instan pisang goroho hal ini disebabkan tingginya kandungan protein pada bubur instan pisang goroho sehingga komposisi protein bertambah dan karbohidrat berkurang.

Hasil kurva respon glikemik menunjukkan hasil rata-rata puncak peningkatan kadar glukosa darah yaitu pada menit ke-15 sampai menit ke-30, dan setelah itu mengalami penurunan kembali. 
Jurnal Teknologi Pertanian Volume 11 Nomor 2 Desember 2020

Serat

Maks.5

4,92

2,00

2,91

1,49 
Tabel 2. Jumlah Porsi Pangan Acuan Yang diberikan

\begin{tabular}{ccccc}
\hline Produk & $\begin{array}{c}\text { Karbohidrat by } \\
\text { difference } \\
(\% \text { bb) }\end{array}$ & $\begin{array}{c}\text { Kadar Serat } \\
(\% \text { bb) }\end{array}$ & $\begin{array}{c}\text { Available } \\
\text { carbohydrate } \\
(\% \text { bb })\end{array}$ & Jumlah porsi \\
\hline F01 & 56,98 & 4,92 & 52,06 & 96,04 \\
F02 & 60,92 & 2,00 & 58,92 & 84,86 \\
F03 & 67,78 & 2,91 & 64,87 & 77,07 \\
F04 & 64,28 & 1,49 & 62,79 & 79,63 \\
\hline
\end{tabular}

Menurut Susanti dkk (2018), kadar glukosa darah puasa yang awalnya berkisar 80-100 $\mathrm{mg} / \mathrm{dL}$ setelah mengkonsumsi makanan yang mengandung karbohidrat maka akan menyebabkan terjadinya peningkatan kadar glukosa darah pada kisaran 120-140 $\mathrm{mg} / \mathrm{dL}$ pada periode waktu 30 menit hingga 1 jam. Hasil analisis kurva respon glukosa darah pada penelitian ini yaitu perubahan kadar glukosa darah pada pangan acuan glukosa murni lebih tinggi jika dibandingkan dengan pangan uji bubur instan.

Nilai IG dikelompokkan dalam 3 kategori yaitu IG rendah $(\mathrm{IG}<55)$, IG sedang (IG 55-70), dan IG tinggi (IG>70). Nilai indeks glikemik bubur instan pisang goroho, bubur instan pisang "mulubebe", bubur instan sagu baruk, bubur instan mocaf dapat dilihat pada tabel 3.

Tabel 3. Nilai Indeks Glikemik Pangan

\begin{tabular}{lcl}
$\begin{array}{l}\text { Pangan } \\
\text { Uji }\end{array}$ & $\begin{array}{c}\text { Nilai } \\
\text { Indeks } \\
\text { Glikemik }\end{array}$ & Kategori \\
\hline F01 & 31,88 & Rendah \\
F02 & 43,35 & Rendah \\
F03 & 39,43 & Rendah \\
F04 & 59,34 & Sedang \\
\hline
\end{tabular}

Berdasarkan perhitungan nilai IG, didapat hasil bahwa nilai IG bubur instan pisang goroho yaitu 31,88 , bubur instan pisang "mulubebe" yaitu 43,35, dan bubur instan sagu baruk yaitu 39,43 termasuk dalam kategori pangan dengan IG rendah $(<55)$, sedangkan nilai IG bubur instan mocaf 59,34 termasuk termasuk dalam kategori pangan IG sedang (55-70).

Menurut Bahado-Singh dkk (2011), pangan yang mengandung lemak dan protein yang tinggi memiliki IG yang lebih rendah karena lemak dan protein cenderung memperlambat laju pengosongan lambung dan respon kenaikan glukosa darah lebih lambat.

Pada hasil penelitian ini bubur instan pisang goroho memiliki kandungan lemak per sajian 45 gr adalah 3,33 gram dan protein7,83 gram, bubur instan pisang "mulubebe" memiliki kandungan lemak 3,35 gram dan protein 7,50 gram, bubur instan sagu baruk memiliki kandungan lemak 3,13 gram dan protein 6,27 gram, sedangkan bubur instan mocaf memiliki kandungan lemak 3,88 gram dan protein 6,81. Hasil ini menunjukkan bahwa kadar lemak dan protein tidak memiliki pengaruh spesifik terhadap indeks glikemik. Beberapa hasil penelitian sebelumnya menjelaskan bahwa kandungan protein dan lemak pada produk pangan tidak mempengaruhi kadar glukosa darah dan nilai indeks glikemik pangan secara nyata (Moghaddam dkk, 2006; Bell dkk, 2015).

Faktor lain yang mempengaruhi IG suatu produk pangan adalah kadar serat pangan. Serat pangan adalah komponen utama yang menyusun dinding sel pada tumbuhan. Berdasarkan hasil 
analisis dapat dapat dilihat bahwa bubur instan pisang goroho, bubur instan sagu baruk dan bubur instan pisang "mulubebe" memiliki nilai IG rendah memiliki kandungan serat total tinggi yaitu 4,92 g, dan 2,91 g dan 2,00 g. Sedangkan bubur instan mocaf memiliki kandungan serat 1,49 gram dan termasuk dalam kategori IG sedang. Kandungan serat total yang tinggi pada bubur instan ini juga dikarenakan terdapat penambahan tepung tempe.

Tepung tempe mengandung serat total sebanyak 5,38\%. Sedangkan kadar serat total pada tepung pisang goroho 5,12 gram \%. Penelitian Ria dkk (2019), menunjukkan bahwa penggunaan tepung pisang goroho yang mengandung serat tinggi sebagai bahan baku pembuatan crust pie dapat meningkatkan kadar serat produk. Hasil ini menunjukkan terdapat kecenderungan bahwa bubur instan dengan kadar serat lebih tinggi memiliki nilai IG lebih rendah.

Proses pengolahan dapat mengakibatkan peningkatan nilai IG pangan karena proses pengolahan dapat membuat struktur pada bahan pangan jadi lebih mudah dicerna dan diserap oleh tubuh dan membuat kadar glukosa darah dapat naik dengan cepat (Rimbawan dan Siagian, 2004). Proses pengolahan pada keempat formula bubur instan ini memiliki perlakuan yang sama, yaitu proses pemasakan dan pemanasan. Pada proses pengolahan menyebabkan terjadinya gelatinisasi pati yang membuat granula pati mengembang sehingga enzim pencernaan pada usus lebih mudah mencernanya (Eleazu, 2016). Karbohidrat sederhana lebih mudah dicerna oleh tubuh menyebabkan peningkatan kadar glukosa darah dengan cepat, sedangkan penyerapan karbohidrat kompleks berlangsung lebih lama (Kustanti dkk, 2017).

Nilai indeks glikemik yang berbeda ini disebabkan karena bahan baku sumber karbohidrat yang digunakan berbeda. Menurut Suloi dkk (2020), bahan baku yang mengandung tinggi karbohidrat dapat mempengaruhi nilai indeks glikemik produk yang dihasilkan. Karbohidrat yang berasal dari tanaman yang berbeda mempunyai respon glikemik yang berdeda (Arif dkk, 2013). Faktor yang mempengaruhi nilai IG pangan sumber karbohidrat adalah rasio amilosa dan amilopektin.

Amilosa dan amilopektin ialah komponen yang terdapat dalam pati. Menurut Lovegrove dkk (2017), amilosa adalah bagian pati yang mempunyai struktur lurus yang dapat membuat enzim pencernaan sulit untuk memecahnya dan menjadi lambat dicerna dan tidak meningkatkan kadar glukosa darah, sedangkan amilopektin memiliki struktur bercabang yang membuatnya lebih mudah dipecah oleh enzim pencernaan dan dapat meningkatkan kadar glukosa darah secara cepat.

Pada penelitian ini menggunakan 4 jenis tepung sumber karbohidrat sebagai bahan utama yaitu tepung pisang goroho, tepung pisang "mulubebe", tepung sagu baruk, dan tepung mocaf. Menurut literatur kadar amilosa tepung pisang goroho adalah $39,59 \%$ dan amilopektin 31,19 (Nurali dkk, 2012). Kadar amilosa tepung pisang "mulubebe" adalah $18,62 \%$ dari total kadar pati 84,33\% (Lumba dkk, 2017). Kadar amilosa tepung sagu adalah $33,12 \%$ darii total kadar pati $79,40 \%$ (Rahmawati dkk, 2019). Sedangkan kadar amilosa tepung mocaf adalah $23,03 \%$ dari total kadar pati $76,97 \%$ (Bayhaqi dan Bahar, 2017).

Pada proses pengolahan bubur instan, tepung sumber karbohidrat ini dicampur dengan tepung lain, sehingga memungkinkan terjadinya perubahan kadar amilosa dan amilopektin tiap pangan uji yang diteliti. Dari keempat jenis tepung sumber karbohidrat ini tepung pisang goroho memiliki 
kandungan amilosa paling tinggi. Hal ini sejalan dengan Penelitian Kadir (2005), yang menyebutkan bahwa pisang merupakan pangan sumber karbohidrat dengan kadar amilosa berkisar antara 27,40\%-46,46\%. Menurut Sangkilen dkk (2019), meneliti kadar amilosa tepung pisang goroho modifikasi memiliki kadar amilosa 21,40\%- 25,54\%. Hal ini membuktikan bahwa dengan tingginya kandungan amilosa pada tepung pisang goroho menjadikan bubur instan pisang goroho memiliki nilai indeks glikemik terendah.

Hasil penelitian Jeevetha dkk (2014), menjelaskan bahwa pangan dengan kadar amilosa lebih rendah akan memiliki nilai IG yang tinggi. Denardin dkk (2012) pada penelitiannya menerangkan bahwa pemberian pangan yang berkadar amilosa tinggi pada tikus menunjukkan respong glukosa darah yang lebih lambat. Rasio amilosa dan amilopektin memberikan pengaruh yang signifikan pada laju dan lama pencernaan pada didalam saluran pencernaan. Hal tersebut disebabkan amilopektin lebih mudah dicerna dibandingkan dengan amilosa (Afandi dkk, 2019).

Menurut penelitian Hanifa dkk (2019), bubur instan yang dibuat dari tepung beras pratanak dan tepung mocaf yang diperkaya tepung bayam merah memiliki IG rendah yaitu 50,5091 sehingga dapat dimanfaatkan sebagai makanan yang baik untuk penderita diabtes melitus. Pada penelitian Fransiska (2018), bubur beras instan memiliki indeks glikemik 64,53, sedangkan bubur beras instan dengan tepung pandan memiliki nilai indeks glikemik 38,75.
Perbedaan nilai indeks glikemik pada produk bubur instan berbahan dasar pangan lokal ini diduga disebabkan oleh faktor-faktor yang mempengaruhi respon glukosa darah dari suatu bahan pangan dalam tubu subjek penelitian diantaranya adalah sifat botani sumber karbohidrat serta penambahan bahan lain pada formula bubur instan.

Bila keempat bubur instan ini disajikan dalam jumlah yang sama yaitu sebanyak $45 \mathrm{~g}$, maka beban glikemik bubur instan pisang goroho sebesar 8,17 sehingga tergolong bernilai BG rendah. Sedangkan nilai beban glikemik bubur instan pisang "mulubebe" sebesar 11,88, bubur instan sagu baruk sebesar 12,02, dan bubur instan mocaf sebesar 17,16 digolongkan bernilai BG sedang. Nilai BG masing-masing bubur instan dapat dilihat pada tabel 4 .

Jika dilihat dari nilai indeks glikemik dan beban glikemiknya, bubur instan pisang goroho memiliki nilai indeks glikemik dan beban glikemik yang rendah yaitu 31,88 dan 8,17 . Bubur instan ini dapat direkomendasikan sebagai pangan fungsional yang memiliki nilai indeks glikemik rendah yang baik untuk penderita diabetes melitus dan juga untuk individu sehat yang ingin mempertahankan kadar glukosa darah. Selain itu, bubur instan pisang goroho juga memiliki kandungan zat gizi protein, lemak, karbohidrat, dan serat yang jika dikonsumsi sebagai makanan tambahan dapat membantu memenuhi kebutuhan gizi orang dewasa.

Tabel 4. Beban Glikemik Bubur Instan Berbasis Pangan Lokal

\begin{tabular}{ccccc}
$\begin{array}{c}\text { Jenis } \\
\text { Pangan }\end{array}$ & IG & $\begin{array}{c}\text { Berat Bubur } \\
\text { per Takaran } \\
\text { Saji }(\mathbf{g})\end{array}$ & $\begin{array}{c}\text { Karbohidrat per } \\
\text { Takaran Saji (g) }\end{array}$ & $\begin{array}{c}\text { Beban } \\
\text { Glikemik }\end{array}$ \\
\hline F01 & 31,88 & 45 & 25,64 & 8,17 \\
F02 & 43,35 & 45 & 27,41 & 11,88 \\
\hline
\end{tabular}




\begin{tabular}{lllll}
\hline F03 & 39,43 & 45 & 30,50 & 12,02 \\
F04 & 59,34 & 45 & 28,92 & 17,16 \\
\hline
\end{tabular}

\section{KESIMPULAN}

Penggunaan sumber karbohidrat dari pangan lokal yang berbeda yaitu tepung pisang goroho, tepung pisang "mulubebe", tepung sagu baruk, tepung mocaf pada bubur instan memberikan pengaruh terhadap kandungan gizi nilai indeks glikemik. Formulasi bubur instan pisang goroho dapat direkomendasikan sebagai pangan fungsional yang memiliki nilai indeks glikemik rendah yang baik untuk penderita diabetes melitus dan juga untuk individu sehat yang ingin mempertahankan kadar glukosa darah.

\section{DAFTAR PUSTAKA}

Abbas. 2020. Potensi Pangan Fungsional dan Peranannya dalam Meningkatkan Kesehatan Manusia yang Semakin Rentan- Mini Review. Jurnal Teknosains Volume 14, No.2 Juli-Desember 2020, hlm. 176-186.

Afandi, F.A., Wijaya, C.H., Faridah, D.N. dan Suyatna, N.E. 2019. Hubungan Antara Karbohidrat dan Indeks Glikemik pada Pangan Tinggi Karbohidrat. Artikel Penelitian 2019.

Anandito, R.,Siswanti. dan Kusumo D.T. 2016. Kajian karakteristik sensoris dan kimia bubur instan berbasis tepung millet putih (Panicum milleceum L.) dan tepung kacang merah (Phaseolus vulgaris L.). Jurnal Teknologi Hasil Pertanian, Vol IX, No.1, Februari 2016.

Arif, A.B., Budiyanto, A.dan Hoerudin. 2013. Nilai indeks glikemik produk pangan dan faktor-faktor yang mempengaruhinya. $J$ litbang Pert Vol 32 no.3 September 2013 :91-99.
Bahado-Singh., Rilley, C.K. dan Wheatley, A.O. 2011. Relationship Between Processing Method and The Glycemic Indices of Sweet Potato (Ipomoea batatas) Cultivars Commonly Consumed in Jamaica. Journal of Nutrition and Metabolism 2011.

Bayhaqi, A. dan Bahar, A. 2017. Pengaruh Substitusi Tepung Mocaf (Modified Cassava Flour) dan Penambahan Puree Wortel (Daucus Carota L.) terhadap Hasil Jadi Pizza. Jurnal Tata Boga Vol 6 No.1 (2017).

Bell, K.J., Smart, C.E., Steil, G.M., Brand-Miller, J.C., King, B., dan Wolpert, H.A. 2015. Impact on Fat, Protein and Glycemic Index on Postprandial Glucose Control in Type 1 Diabetes : Implications for Intensive Diabete Management in The Continuous Glucose Monitoring Era. Diabetes Care Volume 38, June 2015; 10081015.

Dernardin, C.C., Boufleur, N., Reckziegel, P., Da Silva, L.P. dan Walter, M. 2012. Amylose Content in Rice (Oryza sativa) Affects Performance, Glycemic and Lipidic Metabolism in Rats. Ciencia Rural 42 (2): 381-387.

Diyah, N.W., Ambarwati, A., Warsito, G.M., Niken, E., Heriwiyanti, E.T., Windysari, R., Prismawan, D., Hartasari, R.,dan Purwanto, 2016. Evalusasi Kandungan Glukosa dan Indeks Glikemik dalam Upaya Penggalian Pangan Ber-Indeks Glikemik Rendah. Jurnal Farmasi dan kefarmasian Vol. 3 No. 2 Desember 2016.

Eleazu, C.O. 2016. The Concept of Low Glycemic Index and Glycemic 
Index and Glycemic Load Foods as Panaca for Type 2 Diabetes Mellitus; Prospects, Challenges and Solutions. African Health Sciences 16(2) : 468-479.

Fransiska, M. 2018. Penentuan indeks glikemik bubur instan yang diperkaya tepung pandan (Pandanus Amarillipolus Roxb). Seminar Nasional "Inovasi Pangan Lokal Untuk Mendukung Ketahanan Pangan" Universitas Mercu Buana Yogyakarta, April 2018, ISSN : 2656-6796.

Hanifah, Z.N., Lubis, L.M. dan Ginting, S. 2019. Glycemic index of instant porridge from parboiled rice flour and mocaf flour fortified with red spinach flour. IOP conf. series : Earth and Enviromental Science 454 (2020) 012104.

Jeeveta, S., Nisak, M.Y.B., Ngan, H.B., Ismail, A., dan Azlan, A. 2014. Relationship Between Amylose Content and Glycemic Index Of Commonly Consumed White. Journal of Agriculture and Veterinary Science 7 (9) : 12-18.

Kadir, S. 2005. Karakterisasi Tepung Empat Varietas Pisang di Lembah Palu. J. Agrosains 6 (1) : 1-6, April 2005.

Kustanti, I.H., Rimbawan. dan Fuqron LA. 2017. Formulasi Biskuit Rendah Indeks Glikemik (BATIK) dengan Substitusi Tepung Pisang Klutuk (Musa Balbasiana Colla) dan Tepung Tempe. Jurnal Aplikasi Teknologi Pangan 6 (1) 2017.

Lovegrove, A., Edwards, C.H., De Nani, I., Patel, H., El, S.N., Grassby, T., Zielke, C., Ulmius, M., Nielson, L., Butterworth, P.J., Ellis, P.R., dan Shewry, P.R. 2017. Role of Pollysaccharides in Food, Digestion, and Health. Critical Reviews in Food Science and
Nutrition 2017, Vol.57, No.2; 237 253.

Lumba, R., Djarkasi, G.S.S., dan Molenaar, R. 2017.Modifikasi tepung pisang mulubebe (Musa Acuminata) Indigenous Halmahera Utara sebagai sumber pangan prebiotic. Jurnal teknologi pertanian volume 8 nomor 1 .

, Mulyantan, A., dan Yusniar, M. 2019. Analisis Komposisi Kimia Tepung Pisang "Mulubebe" Indigenous Halmahera Utara Sebagai Sumber Pangan Lokal. Jurnal UNIERA Volume 8, Nomor 1; ISSN 2086-0404.

Monghaam, E., Vogt, J.A., dan Wolever, T.M.S. 2006. The effects on Fat and Protein on Glycemic Response in Non Diabetic Humans Vary with Waist Circumference, Fasting Plasma Insulin and Dietary Fiber Intake. The Journal of Nutrition 136 : 2506-2511, 2006.

Nurakhirawati., Nurhaeni., dan Irpan. 2016. Retensi Fenolat Bubur Fungsional Selama Penyimpanan Pada Suhu Ruang. KOVALEN, 2 (2) :77-84 September 2016.

Nurali, E.J.N., Djarkasi, G.S.S., dan Lalujan, E.L. 2012. The Potential of Goroho Plantain As A Source of Functional Food. Laporan Hasil Penelitian Tropical Plant Curiculum Project in Cooperation with USAID-TEXAS A\&M University 2012.

Puspita, Suleman, A., dan Damayanti. 2019. Snack Bar Berbaham Pati Sagu (Metroxylon Sp.), Tempe dan Beras Hitam Sebagai Pangan Fungsional Berindeks Glikemik Rendah. Jurnal Gizi Indonesia Vol.8 No.1, Desember 2019 (1123). 
Ria, N., Rawung, D., dan Nurali, E.J.N. 2019. Pemanfaatan Tepung Komposit Pisang Goroho (Musa acuminate) dan Ubi Jalar Kuning (Ipomoea batatas. L) Sebagai Bahan Baku Pembuatan Crust Pie. Jurnal Teknologi Pertanian Volume 10 No.2 Desember 2019.

Rimbawan, dan Siagian, A. 2004. Indeks glikemik pangan. Penebar Swadaya, Bogor.

Setiarto, R., Widhyastuti, N., dan Sumariyadi, A. 2018. Peningkatan kadar pati resisten tipe III tepung Singkong termodifikasi melalui fermentasi dan Pemanasan bertekanan-pendinginan. BIOPROPAL INDUSTRI Vol. 9 No.1, Juni 2018 :9-23.

Spiraliga, R.R., Damayanto, Y.S., dan Amalia, U. Pengolahan Nasi menggunakan rumput lain . $J$. Peng dan Biotek Hasil Pi- vol.6 No.o2 Th 2017-1.

Suloi, A., Rumitasari., Farid, J.A., Fitriani, S., dan Ramadhani, N.L. 2020. Snack Bars : Camilan Sehat Rendah Indeks Glikemik Sebagai Alternatif Pencegahan Penderita Diabetes. Jurnal Abdi Vol.2 No.1 Januari 2020.

Susanti, A., Wijanarka, A., dan Nareswara, A.S. 2018. Penentuan Indeks Glikemik Pada Cookies Tepung Beras Merah (Oryza nivara) dan Biji Kecipir (Psophocarpus tetragonolobus. L). Ilmu Gizi Indonesia, Vol.02 No.1 Agustus 2018: 69-78.

Tarigan, E.P., Momuat, L.I., dan Suryanto, E. 2015. Karakterisasi dan Aktivitas Antioksidan Tepung Sagur Baruk (Arenga mocrocapha). Jurnal MIPA Unsrat Online 4 (2) 125-130.

Warsito, H, dan Sa'diyah, K. 2019. Pembuatan Klepon dengan Substitusi Tepung Sagu sebagai
Alternatif Makanan Selingan Indeks Glikemik Rendah. Jurnal Kesehatan Vol. 7.No. 1. April 2019. 